University of Nebraska - Lincoln

DigitalCommons@University of Nebraska - Lincoln

Mammalogy Papers: University of Nebraska

State Museum

Museum, University of Nebraska State

$1-1-1969$

\title{
Systematic Status of the Mastiff Bat, Eumops perotis renatae Pirlot, 1965
}

James D. Smith

University of Kansas

Hugh H. Genoways

University of Nebraska - Lincoln, h.h.genoways@gmail.com

Follow this and additional works at: https://digitalcommons.unl.edu/museummammalogy

Part of the Zoology Commons

Smith, James D. and Genoways, Hugh H., "Systematic Status of the Mastiff Bat, Eumops perotis renatae Pirlot, 1965" (1969). Mammalogy Papers: University of Nebraska State Museum. 92.

https://digitalcommons.unl.edu/museummammalogy/92

This Article is brought to you for free and open access by the Museum, University of Nebraska State at DigitalCommons@University of Nebraska - Lincoln. It has been accepted for inclusion in Mammalogy Papers: University of Nebraska State Museum by an authorized administrator of DigitalCommons@University of Nebraska Lincoln. 


\title{
SYSTEMATIC STATUS OF THE \\ MASTIFF BAT, EUMOPS PEROTIS RENATAE PIRLOT, 1965
}

\author{
by
}

\author{
James D. Smith and Hugh H. Genoways
}

\begin{abstract}
Eumops perotis renatae, décrit par Pirlot en 1965 et élevé au rang d'espèce par le même auteur, est considéré ici comme un synonyme plus récent d'Eumops perotis perotis (Schinz, 1821). D'anciennes captures de la grande Eumops d'Amérique du Sud sont reconsidérées à la lumière des notions actuelles sur les relations existant entre Eumops perotis et E. trumbulli.
\end{abstract}

The mastiff bats of the genus Eumops occupy a geographic area from the southewestern United States southward to northern Argentina. Sanborn (1932) reviewed the genus, based on the few specimens then in existence, but no general summary of the systematics and distribution of these bats has since appeared. Unfortunately, the paucity of material presently available still precludes an extensive review of the genus.

Pirlot (1965) described Eumops perotis renatae from Cumaná, Suere, Venezuela. based on an adult female preserved in alchohol. This individual was killed with a slingshot by a small boy on an unknown date in the early 1960's near the municipal stadium in Cumana. Because of its size and curious character, the bat was taken to the Colegio San José, where a biology teacher, R. P. C. Prieto, preserved it in spirits and placed it in the school's biological collection. It was there that Pirlot discovered the bat. In the exceedingly brief original description, he commented on its large size, in contrast to the species perotis as understood by him, and suggested that it possibly represented a distinct species. However, because he had no comparative material at hand, the specimen was provisionally named as a subspecies of $E$. perotis. Later, in a paper on the bats of the upper Amazonian region of Perú, Pirlot (1968:89-90) reported a series of 15 specimens of Eumops, which he regarded as perotis based on a comparison of forearm measurements with those given by Hall and Kelson (1959:210) for that species. Because the holotype of renatae was markedly larger than 
the Peruvian bats thus identified as perotis, Pirlot elevated renatae to specific status.

While teaching in the Biology Department at the Universidad de Oriente at Cumaná, one of us (Smith) learned that the holotype of renatae had been redeposited by Pirlot in the biological collection of the Colegio San José. Sr. Prieto, realizing the value of this specimen, kindly gave it to Smith to be donated to the Museum of Natural History, The University of Kansas, where it was later catalogued as $\mathrm{KU} 115920$. The skull, which was partially broken at the time of collection, has recently been extracled and repaired.

Sanborn (1932) recognized four geographic races of the species Eumops perotis as follows : perotis (Schinz) of the Amazon basin; dabbenei Thomas from northern Argentina ; turmbulli (Thomas), then known only from Para, Brazil; and californicus (Merriam) from southern California, parts of Arizona, and adjacent northern México. Subsequently, Sanborn (1949:283-284) accorded specific status to Eumops trumbulli, which closely resembles perotis except that it is smaller (Table 1 and Fig. 1) and paler in color. This arrangement has been followed recently by Cabrera $(1959: 127)$ and Husson $(1962: 248-250)$. The close resemblance of these two spe-

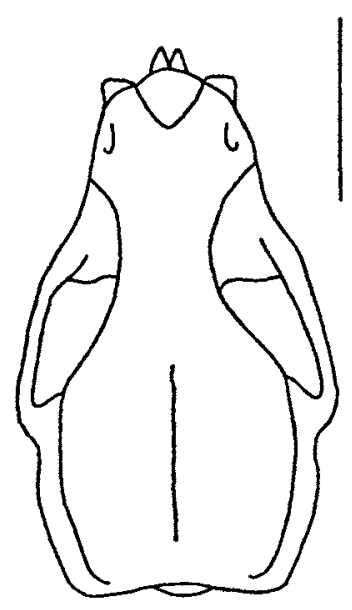

A

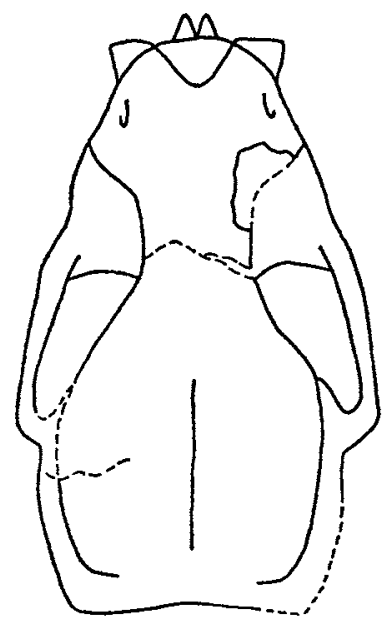

B

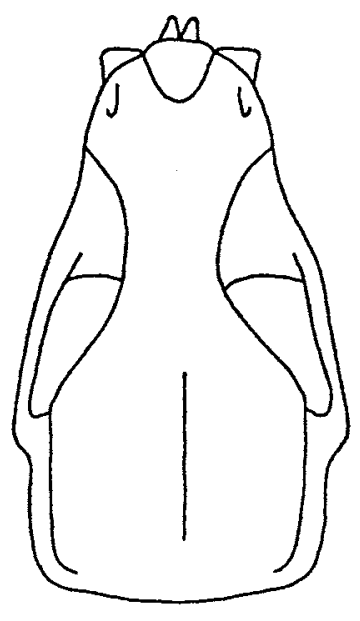

C

Fig 1. - Crania of Eumops trumbulli (A, KU 119178), Eumops perotis (B, holotype of $E$. p. renatae, KU 115920), and Eumops perotis californicus (C, KU 4706). All specimens shown are females and the dotted lines on the holotype of renatae (B) indicate fractures or missing portions of the skull. The vertical line between $A$ and $B$ is 10 millimeters in length. 
TABLE 1

Selected external and cranial measurements

of Eumops perotis and E. trumbulli. All measurements are in millimeters.

Superscript numbers indicate sample size different from those given in left-hand column

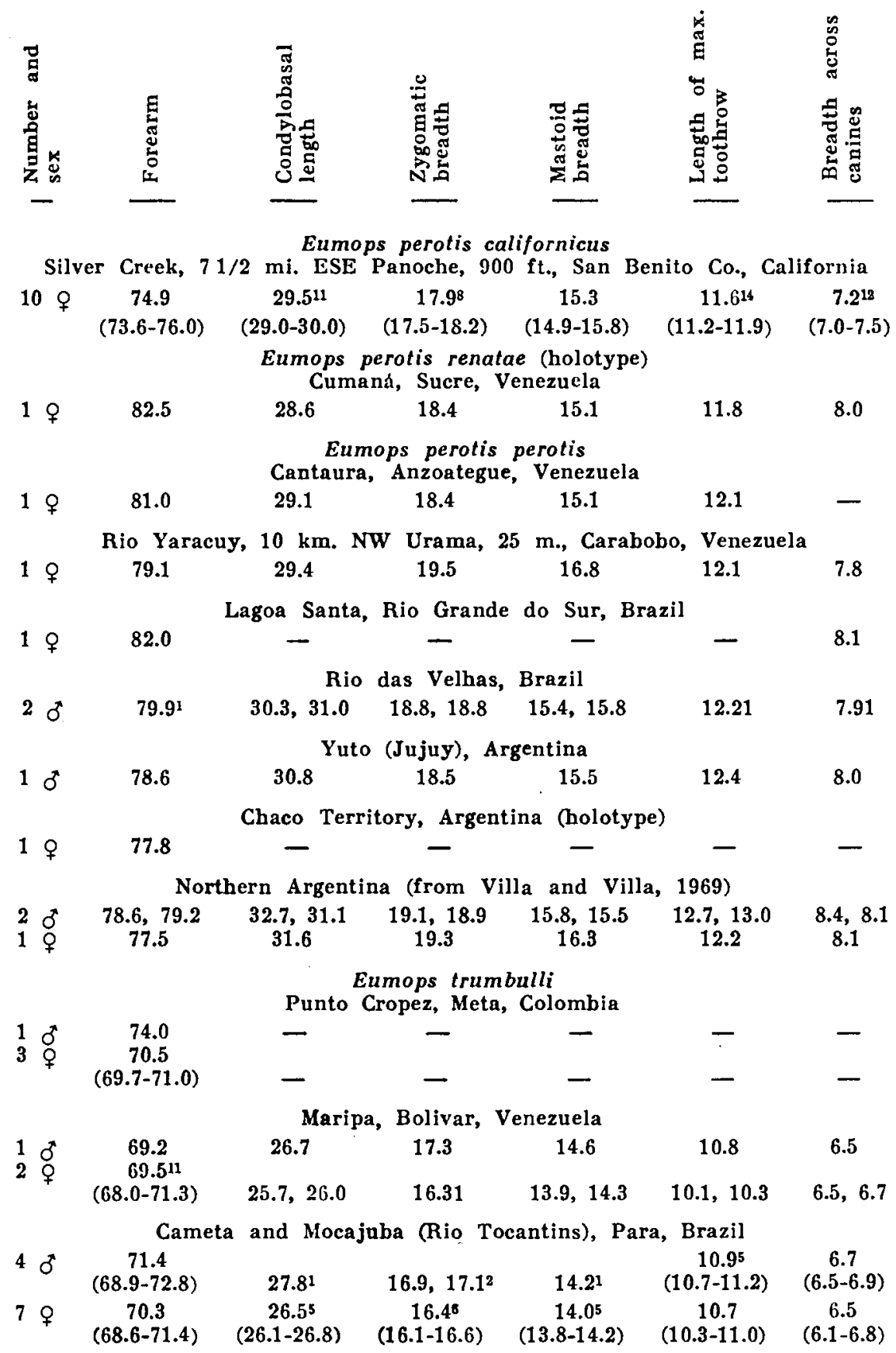


cies was shown also by Brown (1967 : 654), who found perotis and trumbulli were the only members of the genus that lacked an os penis. Cabrera (1959 : 126-127) placed Eumops dabbenei Thomas in synonymy under $E$. p. perotis because material available to him from northern Argentina could not be separated from typical perotis from Brazil. Until additional material is available from the critical regions of southern Brazil and northern Argentina, it seems appropriate to follow Cabrera's arrangement.

In order to determine the systematic status of renatae, the holotype was compared with available material of $E$. perotis. Because trumbulli evidently is more closely related to perotis than to any other species of the genus and because the two so closely resemble each other, specimens of trumbulli also were studied. Selected cranial and external measurements of most of the material examined are given in Table 1. All measurements are in millimeters.

On the basis of external and cranial measurements renatae is clearly a member of the species Eumops perotis. The holotype of renatae agrees also with specimens of perotis as regards color, size and shape of the tragus and antitragus, and size and topography of the dentition. Moreover, the type locality of renatae lies within the geographic range of $E$. $p$. perotis as understood by Cabrera (1959: 127) and there appears to be no reason to separate the two on the basis of measurements (Table 1) or other external or cranial characters. We therefore place Eumops perotis renatae Pirlot, 1965, as a junior synonym of Eumops perotis perotis (Schinz, 1821).

At this point, it seems appropriate to comment on the reports of other supposed perotis from South America. In the paper on the bats of Perú mentioned above, Pirlot (1968 : 90) gave forearm measurements of the 15 specimens that he identified as $E$. perotis; the mean and (extremes) of these are for five males, 70.8 (65.7-73.1), and for 10 females, 71.4 (66.4-74.2). Based on these measurements, it seems highly probable to us that these bats are not perotis, but rather the smaller $E$. trumbulli, which is known to occur in western South America.

Earlier, de la Puente (1951 : 42-44) had reported two individuals (a subadult male and an adult female) from near Lima, Perú, as Eumops perotis californicus. Sanborn (1932: 351) distinguished the subspecies californicus from E. p. perotis principally on the 
basis of a narrower rostrum of $E$. p. californicus (see Table 1 and Fig. 1). Judging by the published external and cranial measurements, these bats are indeed perotis. However, the breadth across the canines and zygomatic breadth (8.5 and 8.4, and 16.9 and 18.2 for male and female, respectively) place these specimens closer to $E$. p. perotis than to californicus. The allocation of these two specimens to californicus seems to have resulted from comparison with three Brazilian specimens (from the Rio Tocantins, Para) that were identified as $E$. p. perotis, but which clearly fall into the size range of E. trumbulli.

In his contribution to the chiropteran fauna of western Ecuador, Brosset (1965 : 223), reported $E$. perotis from Ecuador for the first time, based on two specimens from Guayaquil. One of these, a juvinal inale, had a forearm length of 82 , which along with several selected cranial measurements clearly places it in the size range of perotis. A second adult (sex not given) in the Paris Museum was reported to have a forearm that measured 76. Although, this measurement is at the lower extreme of variation in perotis, it seems probable that this specimen is a small female of that species. The largest forearm of $E$. trumbulli examined by us, a male, measured 74.0 .

\section{ACKNOWLEDGMENTS}

We sincerely thank R. P. C. Prieto for donating the holotype of renatae to the Museum of Natural History at Kansas. We are also grateful to Miss Barbara Lawrence (Museum of Comparative Zoology, Harvard University), Dr. C. O. Handley, Jr. (U. S. National Museum), Dr. Karl F. Koopman (American Museum of Natural History), Dr. W. Z. Lidicker, Jr. (Museum of Vertebrate Zoology, University of California at Berkley), and Dr. R. L. Peterson (Roya] Ontario Museum) for allowing us to examine material pertinent to this study, and to Dr. J. Knox Jones, Jr., who critically reviewed the manuscript.

\section{SUMMARY}

The mastiff bat, Eumops perotis renatae, described by Pirlot in 1965 and later elevated to specific status by the same author is herein regarded as junior synonym of Eumops perotis perotis (Schinz, 1821). Earlier reports of large Eumops from South America are reviewed in light of the present understanding of the relationship between Eumops perotis and E. trumbulli.

Museum of Natural History, The University of Kansas, Lawrence, Kansas 66044 U.S.A. 


\section{BIBLIOGRAPHY}

Brosset, A., 1965. - Contribution à l'étude des chiroptères de l'ouest de l'Ecuador. Mammalia, 29 : 211-227.

Brows, R. E., 1967. - Bacula of some New World molossid bats. Mammalia, 31 : 645-667.

Cabrera, A., 1959. - Catalogo de los mamiferos de America del Sur. Rev. Mus. Argentino Cienc. Nat., Buenos Aires, $4:$ IV $+1-307$.

De la Puente-D., J. O., 1951. - Estudia monofraftco de los quiropteros de Lima y alrededores. Publ. Mus. Hist. Nat. Javier Prado, ser. A, 7 : $1-48$.

Hali, E. R., and K. R. Kelson, 1959. - The mammals of North America. Ronald Press, New York, 1 : $\mathrm{xxx}+1-546$.

Husson, A. M., 1962. - The bats of Suriname. Rijksmus. Nat. Hist., Leiden, $58: 1-282+\mathrm{xxx}$ pls.

Pialot, P., 1965. - Deux formes nouvelles de chiroptères des genres Eumops et Leptonycteris. Naturaliste Canadien, $92: 1-7$.

Pincot, P., 1968. - Chiroptères du Pérou, spécialement de Haute-Amazonie. Mammalia, 32 : 86-96.

Sanbonn, C. C., 1932. - The bats of the genus Eumops. Jour. Mamm., 13 : 347-457.

Sanbonn. C. C., 1949. - Mammals from the Rio Ucayali, Peru. Jour. Mamm., $30: 277-288$.

VillaA-R., B., and M. ViLla-C., 1969. - Algunos murciélagos del norte de Argentina. Misc. Publ. Mus, Nat. Hist., Univ. Kansas, 51 : 407-428. 